\title{
MENGENAL TEORI-TEORI BELAJAR
}

\author{
Oleh: Ramses Simanjuntak, M.Pd.K
}

\begin{abstract}
Signs of people learn can be seen from the occurrence of transformation in a person. Transformation is a change of behavior. Behavioral change touches the three domains of education within the learner, the cognitive domain, the affective domain, and the psycotor realm or better known as the domain of knowledge, the sphere of attitude, and the skill domain. Learning is essentially a change that occurs within a learner after the end of a learning activity. Because after a person ends learning activities there is usually knowledge and insight informed to the learner, which makes the learner think and contemplate the results of learning, so he can take a decision from the learning results.
\end{abstract}

Keywords: Learn, learning theories, behavior change, learning experience.

\begin{abstract}
Abstrak
Tanda orang belajar dapat terlihat dari terjadinya transformasi dalam diri seseorang. Transformasi adalah terjadinya perubahan tingkah laku. Perubahan tingkah laku menyentuh 3 ranah pendidikan dalam diri pembelajar, yakni ranah kognitif, ranah afektif, dan ranah psikmotorik atau yang lebih dikenal dengan ranah pengetahuan, ranah sikap, dan ranah keterampilan. Belajar pada hakikatnya adalah perubahan yang terjadi di dalam diri seseorang pembelajar setelah berakhirnya melakukan aktifitas belajar. Sebab setelah seseorang mengakhiri aktivitas belajar biasanya ada pengetahuan dan wawasan yang diinformasikan kepada pembelajar, yang membuat pembelajar berpikir dan merenungkan hasil belajarnya, sehingga ia dapat mengambil sebuah keputusan dari hasil belajarnya tersebut.
\end{abstract}

Kata Kunci: Belajar, Teori2 Belajar, Perubahan Tingkah Laku, Pengalaman Belajar

\section{Pendahuluan}

Dalam penulisan jurnal yang berjudul "Belajar dan Teori-Teori Belajar”, penulis mencoba untuk mengetengahkan fakta-fakta yang valid dan aktual tentang macam-macam ilmu teori belajar yang gunanya sebagai karya ilmiah untuk memberikan kontribusi bagi banyak orang.

\footnotetext{
${ }^{1}$ Penulis adalah Dosen Pendidikan Agama Kristen di STT Nazarene Indonesia.
} 
Dalam kegiatan belajar mengajar, anak adalah sebagai subyek dan obyek dari kegiatan pengajaran. ${ }^{2}$ Karena itu inti proses pengajaran tidak lain adalah kegiatan belajar mengajar anak didik dalam mencapai suatu tujuan pengajaran. ${ }^{3}$ Tujuan pengajaran tentu saja akan dapat tercapai jika anak didik berusaha secara aktif untuk mencapainya dan anak didik tersebut merasakan perubahan di dalam dirinya. ${ }^{4}$

Belajar merupakan sebuah proses yang terjadi pada semua orang dan berlangsung seumur hidup (sejak bayi sampai meninggal dunia). ${ }^{5}$ Salah satu tanda orang belajar adalah adanya suatu perubahan tingkah laku dalam hidupnya (kogninif, psikomotor, dan afektif). Belajar pada hakikatnya adalah perubahan yang terjadi di dalam diri seseorang setelah berakhirnya melakukan "aktifitas belajar"6. Walaupun pada kenyataannya tidak semua perubahan termasuk kategori belajar. Misalnya perubahan fisik, mabuk, gila dan sebagainya.

Sama halnya dengan belajar, mengajar pun pada hakikatnya adalah suatu proses, yaitu proses mengatur, mengorganisasi lingkungan yang ada di sekitar anak didik, sehingga dapat menumbuhkan dan mendorong anak didik melakukan proses belajar. ${ }^{7}$ Pada tahap berikutnya, mengajar adalah proses memberikan bimbingan atau bantuan kepada anak didik dalam melakukan proses belajar. ${ }^{8}$ Akhirnya dapat disimpulkan bahwa apabila hakikat belajar adalah perubahan, maka hakikat belajar mengajar adalah proses pengaturan yang dilakukan oleh guru.

\footnotetext{
${ }^{2}$ Arif Rohman, Memahami Pendidikan dan Ilmu Pendidikan, (Yogyakarta: LaksBang Mediatama), 2011, hal. 78 .

${ }^{3}$ Made Pidarta, Landasan Pendidikan, (Jakarta: Rineka Cipta), 2007, hal. 16.

${ }^{4}$ Ibid, hal. 17.

${ }^{5}$ Mochtar Bukhori, Pendidikan dalam Pembangunan, (Yogyakarta: PT Tiara Wacana Yogya), 1994, hal. 23.

${ }^{6}$ Dimyati dan Mudjiono, Belajar dan Pembelajaran, (Jakarta: Rineka C PPKn), 2006, hal. 73.

${ }^{7}$ Arif Rohman. Memahami Pendidikan dan Ilmu Pendidikan, (Yogyakarta: LaksBang Mediatama), 2011, hal. 105.

${ }^{8}$ Slameto, Belajar dan Faktor-Faktor yang Mempengaruhinya, (Jakarta: Bumi Aksara), 2010, hal. 54.
} 


\section{Belajar}

Dalam kegiatan belajar dan mengajar di sekolah terjadi sebuah proses yaitu interaksi antara guru dengan siswa, siswa dengan siswa jika terjadi kegiatan belajar kelompok. Dalam interaksi tersebut akan terjadi sebuah proses pembelajaran, pembelajaran secara umum didefinisikan sebagai suatu proses yang menyatukan kognitif, emosional, dan lingkungan pengaruh dan pengalaman untuk memperoleh, meningkatkan, atau membuat perubahan's pengetahuan satu, keterampilan, nilai, dan pandangan dunia ${ }^{9}$.

Belajar sebagai suatu proses berfokus pada apa yang terjadi ketika belajar berlangsung. Penjelasan tentang apa yang terjadi merupakan teori-teori belajar. Teori belajar adalah upaya untuk menggambarkan bagaimana orang dan hewan belajar, sehingga membantu kita memahami proses kompleks inheren pembelajaran ${ }^{10}$.

Bertolak dari perubahan yang ditimbulkan oleh perbuatan belajar, para ahli teori belajar berusaha merumuskan pengertian belajar. Di bawah ini dikutip beberapa batasan belajar, agar dapat menjadi bahan pemikiran dan renungan mengenai pengertian belajar yang berlangsung di kelas.

Belajar proses perubahan tingkah laku seseorang terhadap sesuatu situasi tertentu yang disebabkan oleh pengalamannya yang berulang-ulang dalam situasi itu, di mana perubahan tingkah laku itu tidak dapat dijelaskan atau dasar kecendrungan respon pembawaan, pemaksaan, atau kondisi sementara (seperti lelah, mabuk, perangsang dan sebagainya). ${ }^{11}$

Menurut Clifford Thomas Morgan yang dikutip oleh Ahmadi Abu dan Widodo Supriyono. Dalam "Psikologi Belajar” menyatakan bahwa belajar adalah merupakan salah satu yang relatif

\footnotetext{
${ }^{9}$ Mulyati, Psikologi Belajar, (Yogyakarta: Andi Offset), 2005, hal. 61.

${ }^{10}$ S. Nasution, Berbagai Pendekatan dalam Proses Belajar dan Mengajar, (Jakarta: Bumi Aksara), 2000, hal. 56 .

${ }^{11}$ Lisnawati Simanjutak, Metode Mengajar Matematika, (Jakarta: PT Rineka Cipta), 1993, hal. 99.
} 
tetap dari tingkah laku sebagai akibat dari pengalaman. Dengan demikian dapat diketahui bahwa belajar adalah usaha sadar yang dilakukan manusia melalui pengalaman dan latihan untuk memperoleh kemampuan baru dan merupakan perubahan tingkah laku yang relatif tetap, sebagai akibat dari latihan. ${ }^{12}$ Sedangkan Ernest R. Hilgard dan Gordon H. Bower menyatakan belajar merupakan proses perbuatan yang dilakukan dengan sengaja, yang kemudian menimbulkan perubahan, yang keadaannya berbeda dari perbuatan yang ditimbulkan oleh lainnya. ${ }^{13}$

Selanjutnya menurut Gerow seperti yang dikutip oleh Asri C. Budiningsih dalam "Belajar dan Pembelajaran" mengemukakan bahwa "Learning is demonstrated by a relatively permanent change in behavior that occurs as the result of practice or experience". (Belajar adalah ditunjukkan oleh perubahan yang relatif tetap dalam perilaku yang terjadi karena adanya latihan dan pengalaman-pengalaman) ${ }^{14}$. Kemudian menurut Ernest R. Hilgard dan Gordon H. Bower "Learning is a cognitive process". (Belajar adalah suatu proses kognitif). ${ }^{15}$

Berdasarkan pengertian belajar yang dikemukakan di atas dapat diidentifikasi beberapa elemen penting yang mencirikan pengertian belajar yaitu: belajar adalah merupakan suatu perubahan dalam tingkah laku, dimana perubahan itu dapat mengarah kepada tingkah laku yang baik, tetapi juga ada kemungkinan mengarah kepada tingkah laku yang buruk. Perubahan itu tidak harus segera nampak setelah proses belajar tetapi dapat nampak di kesempatan yang akan datang.

Belajar merupakan suatu perubahan yang terjadi melalui latihan dan pengalaman. Untuk dapat disebut belajar, maka perubahan itu pada pokoknya adalah didapatkannya kecakapan baru,

\footnotetext{
${ }^{12}$ Ahmadi, Abu dan Widodo Supriyono, Psikologi Belajar, (Jakarta: Rineka Cipta), 1991, hal. 99.

13 Ibid, hal. 101.

${ }^{14}$ Budiningsih, C Asri, Belajar dan Pembelajaran, (Jakarta: PT. Rineka Cipta), 2005, hal. 168.

15 Ahmadi, Abu dan Widodo Supriyono, Psikologi Belajar, (Jakarta: Rineka Cipta), 1991, hal. 66.
} 
yang berlaku dalam waktu yang relatif lama. Tingkah laku yang mengalami perubahan karena belajar menyangkut berbagai aspek kepribadian baik fisik maupun phisikis. ${ }^{16}$

Teori manapun pada prinsipnya, belajar meliputi segala perubahan baik berpikir, pengetahuan, informasi, kebiasaan, sikap apresiasi maupun pengertian. Ini berarti kegiatan belajar ditunjukan oleh adanya perubahan tingkah laku sebagai hasil pengalaman. Perubahan akibat proses belajar adalah karena adanya usaha dari individu dan perubahan tersebut berlangsung lama. Belajar merupakan kegiatan yang aktif, karena kegiatan belajar dilakukan dengan sengaja, sadar dan bertujuan. Agar kegiatan belajar mencapai hasil yang optimal, maka diusahakan faktor penunjang seperti kondisi peserta didik yang baik, fasilitas dan lingkungan yang mendukung serta proses belajar mengajar yang tepat. ${ }^{17}$

\section{Teori-Teori Belajar}

Teori Belajar Koneksionisme (Edward Lee Thorndike) ${ }^{18}$

Menurut Thorndike, belajar merupakan peristiwa terbentuknya asosiasi-asosiasi antara peristiwa-peristiwa yang disebut stimulus (S) dengan respon (R). Stimulus adalah suatu perubahan dari lingkungan eksternal yang menjadi tanda untuk mengaktifkan organisme untuk beraksi atau berbuat sedangkan respon dari adalah sembarang tingkah laku yang dimunculkan karena adanya perangsang. Bentuk paling dasar dari belajar adalah "trial and error learning atau selecting and connecting learning" dan berlangsung menurut hukum-hukum tertentu. Oleh karena itu teori

\footnotetext{
${ }^{16}$ Baharuddin dan Esa Nur Wahyuni, Teori Balajar dan Pembelajaran, (Jogjakarta: Ar-RUZZ MEDIA), 2007, hal. 25.

${ }^{17}$ Dahar, Ratna Willis, Teori-Teori Belajar, (Jakarta: Depdikbud Direktorat Jendral Pendidikan Tinggi PPLPTK), 1988, hal. 55.

${ }^{18}$ Fudyartanto, Ki RBS, Psikologi Pendidikan dengan Pendeatan Baru, (Jogjakarta: Global Pustaka Ilmu), 2002, hal. 37.
} 
belajar yang dikemukakan oleh Thorndike ini sering disebut dengan teori belajar koneksionisme atau teori asosiasi.

\section{Teori Belajar Behaviorisme (B.F. Skinner) ${ }^{19}$}

B.F. Skinner dikenal sebagai tokoh behavioris dengan pendekatan model instruksi langsung dan meyakini bahwa perilaku dikontrol melalui proses operant conditioning. Operant Conditioning adalah suatu proses perilaku operant (penguatan positif atau negatif) yang dapat mengakibatkan perilaku tersebut dapat berulang kembali atau menghilang sesuai dengan keinginan. Skinner mengatakan bahwa unsur terpenting dalam belajar adalah penguatan. Maksudnya adalah pengetahuan yang terbentuk melalui ikatan stimulus respon akan semakin kuat bila diberi penguatan. Skinner membagi penguatan ini menjadi dua yaitu penguatan positif dan penguatan negatif. Bentuk bentuk penguatan positif berupa hadiah, perilaku, atau penghargaan. Bentuk bentuk penguatan negatif antara lain menunda atau tidak memberi penghargaan, memberikan tugas tambahan atau menunjukkan perilaku tidak senang.

\section{Teori Belajar Hirarki Belajar (Robert M. Gagne) $)^{20}$}

Gagne membagi proses belajar berlangsung dalam fase utama, dan fase tidak utama, yaitu: 1). Fase Receiving the stimulus situation (apprehending), merupakan fase seseorang memperhatikan stimulus tertentu kemudian menangkap artinya dan memahami stimulus tersebut untuk kemudian ditafsirkan sendiri dengan berbagai cara. 2). Fase Stage of Acquition, pada fase ini seseorang akan dapat memperoleh suatu kesanggupan yang belum diperoleh sebelumnya

${ }^{19}$ John W. Satrock, Psikologi Pendidikan, Edisi Kedua, (Jakarta: PT Kencana Media Group), 2007 , hal. 18.

20 Al Rasyidin dan Wahyudin Nur Nasution, Teori Belajar dan Pembelajaran, (Medan: Perdana Publishing), 2011, hal. 86. 
dengan menghubung-hubungkan informasi yang diterima dengan pengetahuan sebelumnya. 3).

Fase storage/retensi, adalah fase penyimpanan informasi, ada informasi yang disimpan dalam jangka pendek ada yang dalam jangka panjang, melalui pengulangan informasi dalam memori jangka pendek dapat dipindahkan ke memori jangka panjang. 4). Fase Retrieval/Recall, adalah fase mengingat kembali atau memanggil kembali informasi yang ada dalam memori. Kemudian ada fase-fase lain yang dianggap tidak utama, yaitu: 1). Fase motivasi sebelum pelajaran dimulai guru memberikan motivasi kepada siswa untuk belajar, 2). Fase generalisasi, adalah fase transfer informasi, pada situasi-situasi baru, agar lebih meningkatkan daya ingat, siswa dapat diminta mengaplikasikan sesuatu dengan informasi baru tersebut. 3). Fase penampilan, adalah fase dimana siswa harus memperlihatkan sesuatu penampilan yang nampak setelah mempelajari sesuatu, seperti mempelajari struktur kalimat dalam bahasa mereka dapat membuat kalimat yang benar, dan 4). Fase umpan balik, adalah fase dimana siswa harus diberikan umpan balik dari apa yang telah ditampilkan (reinforcement).

\section{Teori Belajar Discovery Learning (Jerome S. Bruner) ${ }^{21}$}

Bruner menyatakan belajar merupakan suatu proses aktif yang memungkinkan manusia untuk menemukan hal-hal baru di luar informasi yang diberikan kepada dirinya.

Agar pembelajaran dapat mengembangkan keterampilan intelektual anak dalam mempelajari sesuatu pengetahuan (misalnya suatu konsep matematika), maka materi pelajaran perlu disajikan dengan memperhatikan tahap perkembangan kognitif/pengetahuan anak agar pengetahuan itu dapat diinternalisasi dalam pikiran (struktur kognitif) orang tersebut. Proses internalisasi akan terjadi secara sungguh-sungguh (yang berarti proses belajar terjadi secara 2007, hal. 36 .

Baharuddin dan Esa Nur Wahyuni, Teori Balajar dan Pembelajaran, (Jogjakarta: Ar-RUZZ MEDIA), 
optimal) jika pengetahuan yang dipelajari itu dipelajari dalam tiga model tahapan yaitu model tahap enaktif, model ikonik dan model tahap simbolik.

Model Tahap Enaktif. Dalam tahap ini penyajian yang dilakukan melalui tindakan anak secara langsung terlibat dalam memanipulasi (mengotak-atik) objek. Pada tahap ini anak belajar sesuatu pengetahuan di mana pengetahuan itu dipelajari secara aktif, dengan menggunakan bendabenda konkret atau menggunakan situasi yang nyata.

Model Tahap Ikonik. Tahap ikonik, yaitu suatu tahap pembelajaran sesuatu pengetahuan di mana pengetahuan itu direpresentasikan (diwujudkan) dalam bentuk bayangan visual (visual imaginery), gambar, atau diagram, yang menggambarkan kegiatan kongkret atau situasi kongkret yang terdapat pada tahap enaktif.

Model Tahap Simbolis. Dalam tahap ini bahasa adalah pola dasar simbolik, anak memanipulasi simbul-simbul atau lambang-lambang objek tertentu. Pada tahap simbolik ini, pembelajaran direpresentasikan dalam bentuk simbol-simbol abstrak (abstract symbols), yaitu simbol-simbol arbiter yang dipakai berdasarkan kesepakatan orang-orang dalam bidang yang bersangkutan, baik simbol-simbol verbal (misalnya huruf-huruf, kata-kata, kalimat-kalimat), lambang-lambang matematika, maupun lambang-lambang abstrak yang lain.

\section{Teori belajar Kognitif (Jean Piaget) $)^{22}$}

Dalam pandangan Piaget, terdapat dua proses yang mendasari perkembangan dunia individu, yaitu pengorganisasian dan penyesuaian. Untuk membuat dunia kita diterima oleh pikiran, kita melakukan pengorganisasian pengalaman-pengalaman yang telah terjadi. Piaget yakin bahwa kita menyesuaikan diri dalam dua cara yaitu asimiliasi dan akomodasi.

${ }^{22}$ Dahar, Ratna Willis, Teori-Teori Belajar, (Jakarta: Depdikbud Direktorat Jendral Pendidikan Tinggi PPLPTK), 1988, hal. 60. 
Asimilasi terjadi ketika individu menggabungkan informasi baru ke dalam pengetahuan mereka yang sudah ada. Sedangkan akomodasi adalah terjadi ketika individu menyesuaikan diri dengan informasi baru.

Piaget mengatakan bahwa kita melampui perkembangan melalui empat tahap dalam memahami dunia, yaitu :

Tahap sensorimotor (Sensorimotor stage), yang terjadi dari lahir hingga usia 2 tahun, merupakan tahap pertama piaget. Pada tahap ini, perkembangan mental ditandai oleh kemajuan yang besar dalam kemampuan bayi untuk mengorganisasikan dan mengkoordinasikan sensasi (seperti melihat dan mendengar) melalui gerakan-gerakan dan tindakan-tindakan fisik.

Tahap praoperasional (preoperational stage), yang terjadi dari usia 2 hingga 7 tahun, merupakan tahap kedua piaget, pada tahap ini anak mulai melukiskan dunia dengan kata-kata dan gambar-gambar. Mulai muncul pemikiran egosentrisme, animisme, dan intuitif.

Tahap operasional konkrit (concrete operational stage), yang berlangsung dari usia 7 hingga 11 tahun, merupakan tahap ketiga piaget. Pada tahap ini anak dapat melakukan penalaran logis menggantikan pemikiran intuitif sejauh pemikiran dapat diterapkan ke dalam cotoh-contoh yang spesifik atau konkrit.

Tahap operasional formal (formal operational stage), yang terlihat pada usia 11 hingga 15 tahun, merupakan tahap keempat dan terkahir dari piaget. Pada tahap ini, individu melampaui dunia nyata, pengalaman-pengalaman konkrit dan berpikir secara abstrak dan lebih logis.

Perlu diingat, bahwa pada setiap tahap tidak bisa berpindah ke tahap berikutnya bila tahap sebelumnya belum selesai dan setiap umur tidak bisa menjadi patokan utama seseorang berada pada tahap tertentu karena tergantung dari ciri perkembangan setiap individu yang bersangkutan 


\section{Teori Belajar Bermakna (David P. Ausubel) ${ }^{23}$}

Ausubel mengemukakan bahwa belajar dikatakan bermakna (meaningful) jika informasi yang akan dipelajari peserta didik disusun sesuai dengan struktur kognitif yang dimiliki peserta didik sehingga peserta didik dapat mengaitkan informasi barunya dengan struktur kognitif yang dimilikinya.

Menurut Ausubel, Novak,dan Hanesian ada dua jenis belajar, yaitu: 1). Belajar bermakna (meaningful learning). Belajar bermakna adalah suatu proses belajar dimana informasi baru dihubungkan dengan struktur penertian yang sudah dipunyai seseorang yang sedang belajar. Belajar bermakna terjadi bila pelajar mencoba menghubungkan fenomena baru dengan konsep yang telah ada sebelumnya. 2). Belajar menghafal (rote learning). Bila konsep yang cocok dengan fenomena baru itu belum ada maka informasi baru tersebut harus dipelajari secara menghafal. Belajar menghafal ini perlu bila seseoarang memperoleh informasi baru dalam dunia pengetahuan yang sama sekali tidak berhubungan dengan apa yang ia ketahui sebelumnya.

Menurut Ausubel belajar dapat diklasifikasikan kedalam dua dimensi. Dimensi pertama berhubungan dengan cara informasi atau materi pelajaran itu disajikan kepada siswa melalui penerimaan atau penemuan. Selanjutnya dimensi kedua menyangkut bagaimana siswa dapat mengaitkan informasi itu pada struktur kognitif yang telah ada. Jika siswa hanya mencoba menghafalkan informasi baru itu tanpa menghubungkan dengan struktur kognitifnya, maka terjadilah belajar dengan hafalan. Sebaliknya jika siswa menghubungkan atau mengaitkan informasi baru itu dengan struktur kognitifnya maka yang terjadi adalah belajar bermakna.

Langkah - langkah belajar bermakna Ausubel adalah: 1). Pengatur awal (advance organizer). Pengatur awal dapat digunakan untuk membantu mengaitkan konsep yang lama

\footnotetext{
${ }^{23}$ Ibid, hal. 65.
} 
dengan konsep yang baru yang lebih tinggi maknanya. 2). Diferensiasi Progregsif. Dalam pembelajaran bermakna perlu ada pengembangan dan kolaborasi konsep- konsep. Caranya unsur yang inklusif diperkenalkan terlebih dahulu kemudian baru lebih mendetail.

\section{Teori Belajar Gestalt (Kurt Koffka) ${ }^{24}$}

Gestalt adalah merupakan salah satu teori yang menjelaskan bahwa proses persepsi melalui pengorganisasian suatu komponen-komponen yang memiliki hubungan, pola, dan juga kemiripan yang bersatu menjadi satu kesatuan. Teori gestalt beroposisi terhadap teori strukturalisme. Teori gestalt cenderung berupaya mengurangi dalam pembagian sensasi menjadi bagian-bagian kecil. Teori Gestalt sendiri terdiri dari 5 aplikasi belajar, yakni:

Pengalaman tilikan (insight); bahwa tilikan memegang peranan yang penting dalam perilaku. Dalam proses pembelajaran, hendaknya peserta didik memiliki kemampuan tilikan yaitu kemampuan mengenal keterkaitan unsur-unsur dalam suatu obyek atau peristiwa. Teori Gestalt sendiri terdiri dari 5 aplikasi belajar, yakni: Pembelajaran yang bermakna (meaningful learning); kebermaknaan unsur-unsur yang terkait akan menunjang pembentukan tilikan dalam proses pembelajaran. Makin jelas makna hubungan suatu unsur akan makin efektif sesuatu yang dipelajari. Hal ini sangat penting dalam kegiatan pemecahan masalah, khususnya dalam identifikasi masalah dan pengembangan alternatif pemecahannya. Hal-hal yang dipelajari peserta didik hendaknya memiliki makna yang jelas dan logis dengan proses kehidupannya; Perilaku bertujuan (pusposive behavior); bahwa perilaku terarah pada tujuan. Perilaku bukan hanya terjadi akibat hubungan stimulus-respons, tetapi ada keterkaitannya dengan dengan tujuan yang ingin dicapai. Proses pembelajaran akan berjalan efektif jika peserta didik mengenal tujuan yang ingin

\footnotetext{
${ }^{24}$ Winataputra, Udin S. Teori Belajar Dan Pembelajaran, (Jakarta: Penerbitan Universitas Terbuka), 2007, hal. 74 .
} 
dicapainya. Oleh karena itu, guru hendaknya menyadari tujuan sebagai arah aktivitas pengajaran dan membantu peserta didik dalam memahami tujuannya; Prinsip ruang hidup (life space); bahwa perilaku individu memiliki keterkaitan dengan lingkungan dimana ia berada. Oleh karena itu, materi yang diajarkan hendaknya memiliki keterkaitan dengan situasi dan kondisi lingkungan kehidupan peserta didik;

Transfer dalam Belajar; yaitu pemindahan pola-pola perilaku dalam situasi pembelajaran tertentu ke situasi lain. Menurut pandangan Gestalt, transfer belajar terjadi dengan jalan melepaskan pengertian obyek dari suatu konfigurasi dalam situasi tertentu untuk kemudian menempatkan dalam situasi konfigurasi lain dalam tata-susunan yang tepat. Judd menekankan pentingnya penangkapan prinsip-prinsip pokok yang luas dalam pembelajaran dan kemudian menyusun ketentuan-ketentuan umum (generalisasi). Transfer belajar akan terjadi apabila peserta didik telah menangkap prinsip-prinsip pokok dari suatu persoalan dan menemukan generalisasi untuk kemudian digunakan dalam memecahkan masalah dalam situasi lain. Oleh karena itu, guru hendaknya dapat membantu peserta didik untuk menguasai prinsip-prinsip pokok dari materi yang diajarkannya.

\section{Kesimpulan}

Aktivitas belajar adalah sebuah aktivitas yang positif dan menyenangkan, ia dapat membantu si pembelajar untuk membangun dirinya sendiri, sehingga si pembelajar dapat meraih begitu banyak ilmu bagi bekal si pembelajara di kemudian hari. Belajar juga dapat mentransformasi diri si pembejar sehingga terbangun menjadi seorang yang lebih baik dalam tingkah laku dan cara berpikirnya. 
Dalam kegiatan belajar ada begitu banyak teori-teori belajar yang harus dipahami dan dikenal oleh pembelajar, karena teori-teori belajar itu membantu pembelajar untuk memahami cara belajar yang baik, sehingga teori-teori itu sedikit banyak memberikan pengetahuan yang objektib dan optimal dalam pengelolaan belajar.

Dalam jurnal ini penulis menghadirkan teori-teori belajar yang dihasilkan melalui penemuan para ahli, seperti Teori Belajar koneksionisme oleh Edward Lee Thorndike, Teori Belajar Behaviorisme oleh B.F. Skinner, Teori Belajar Hirarki Belajar oleh Robert M. Gagne, Teori Belajar Discovery Learning oleh Jerome S. Bruner, Teori belajar Kognitif oleh Jean Piaget, Teori Belajar Bermakna oleh David P. Ausubel, dan Teori Belajar Gestalt oleh Kurt Koffka. Kesemua teori belajar itu mencoba memahami diri masing-masing pembelajar sehingga para pembelajar tinggal menyesuaikan saja apa yang paling cocok bagi dirinya. 


\section{DAFTAR PUSTAKA}

Abu, Ahmadi dan Widodo Supriyono. Psikologi Belajar, Jakarta: Rineka Cipta, 1991.

Baharuddin dan Esa Nur Wahyuni, Teori Balajar dan Pembelajaran, Jogjakarta: Ar-RUZZ MEDIA, 2007.

Budiningsih, C Asri, Belajar dan Pembelajaran, Jakarta: PT. Rineka Cipta, 2005.

Bukhori, Mochtar. Pendidikan dalam Pembangunan, Yogyakarta: PT Tiara Wacana Yogya, 1994.

Dahar, Ratna Willis, Teori-Teori Belajar, Jakarta: Depdikbud Direktorat Jendral Pendidikan Tinggi PPLPTK, 1988.

Dimyati dan Mudjiono. Belajar dan Pembelajaran, Jakarta: Rineka C PPKn, 2006.

Fudyartanto, Ki RBS, Psikologi Pendidikan dengan Pendeatan Baru, Jogjakarta: Global Pustaka Ilmu, 2002.

Mulyati. Psikologi Belajar, Yogyakarta: Andi Offset, 2005.

Nasution, S. Berbagai Pendekatan dalam Proses Belajar dan Mengajar, Jakarta: Bumi Aksara, 2000 .

Pidarta, Made. Landasan Pendidikan, Jakarta: Rineka Cipta, 2007.

Rasyidin, Al dan Wahyudin Nur Nasution. Teori Belajar dan Pembelajaran, Medan: Perdana Publishing, 2011.

Rohman, Arif Rohman. Memahami Pendidikan dan Ilmu Pendidikan, Yogyakarta: LaksBang Mediatama, 2011.

Simanjuntak, Lisnawati. Metode Mengajar Matematika, Jakarta: PT Rineka Cipta, 1993.

Slameto. Belajar dan Faktor - Faktor yang Mempengaruhinya, Jakarta: Bumi Aksara, 2010.

Strock, John W. Psikologi Pendidikan. Edisi Kedua, Jakarta: PT Kencana Media Group, 2007.

Winataputra, Udin S. Teori Belajar Dan Pembelajaran, Jakarta: Penerbitan Universitas Terbuka, 2007. 